\title{
Safe and smart savings products for vulnerable adolescent girls in Kenya and Uganda: Results from the Uganda pilot evaluation
}

Karen Austrian

Population Council

Follow this and additional works at: https://knowledgecommons.popcouncil.org/departments_sbsr-pgy

Part of the Behavioral Economics Commons, Demography, Population, and Ecology Commons, Family, Life Course, and Society Commons, and the International Public Health Commons How does access to this work benefit you? Let us know!

\section{Recommended Citation}

Austrian, Karen. 2011. "Safe and smart savings products for vulnerable adolescent girls in Kenya and Uganda: Results from the Uganda pilot evaluation," presentation at Global Youth Economic Opportunities Conference, Washington, DC, 9 September. 
Safe and Smart Savings Products for Vulnerable Adolescent Girls in Kenya and Uganda: Results from the Uganda Pilot Evaluation

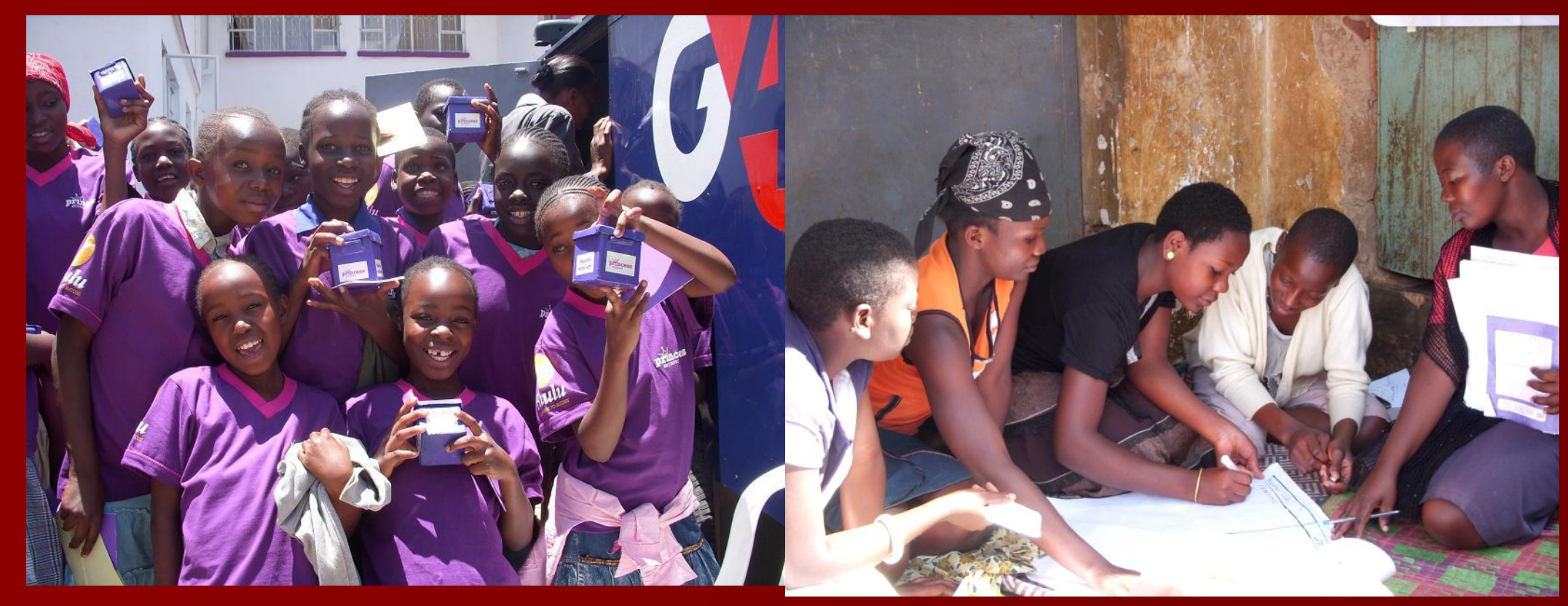

\section{Karen Austrian}

Global Youth Economic Opportunities Conference Washington, DC September 9 $9^{\text {th }}, 2011$ 


\section{Background on Girls Savings Program:}

Building on Prior Health, Financial Education, and Credit Programs

- Savings project builds on a body of work with adolescent girls - both health and livelihood focused

- Programs that offered credit were not meeting the economic or social needs of girls

- Economic situation often trumps their knowledge of healthy behaviors

- Started with Financial Education, but not meeting girls need for safe and secure places to store their money

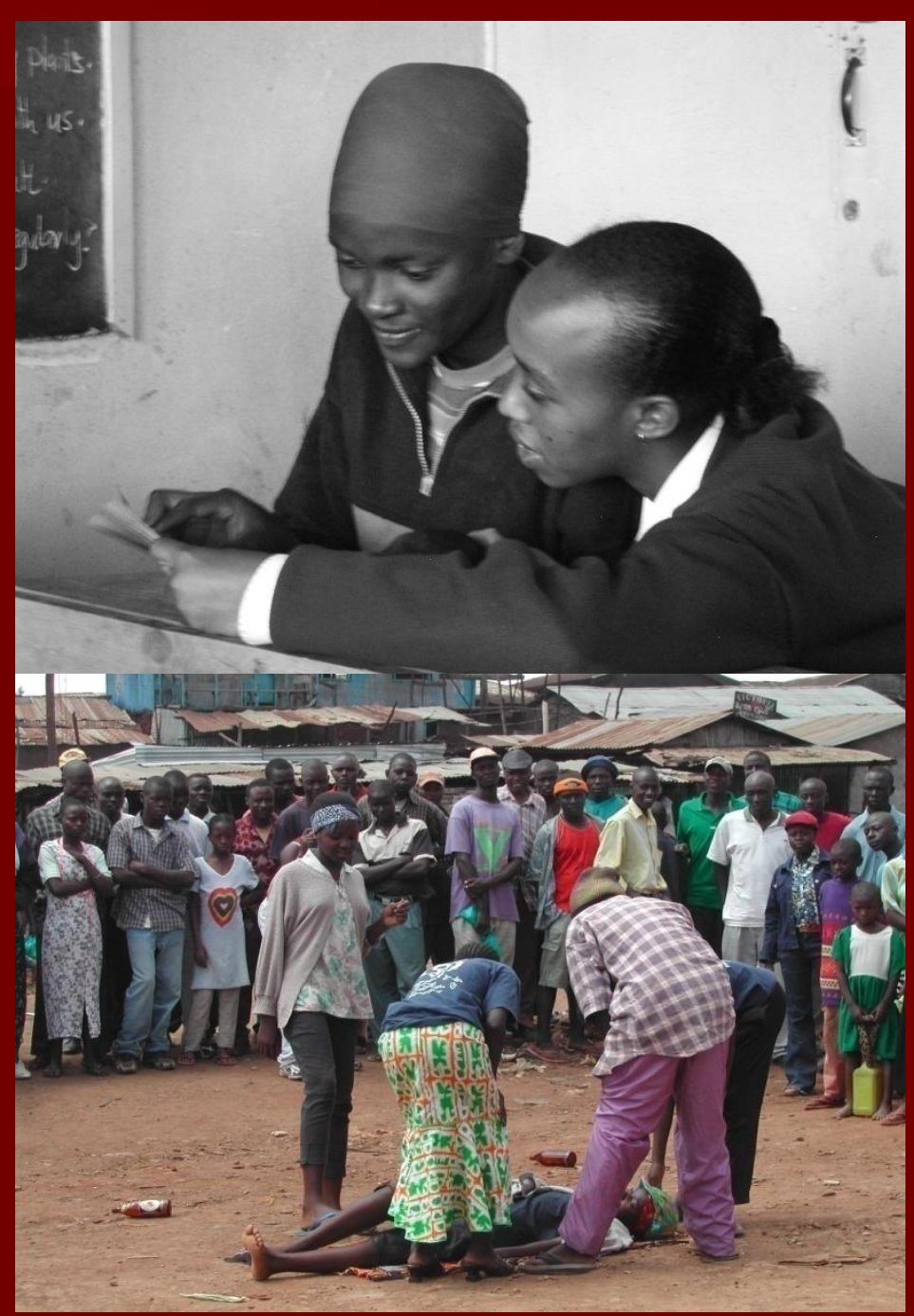




\title{
Asset Building Framework
}

Social + Human + Economic Assets

\author{
-girls need all three
}

Assets are a store of value

ASSETS $\rightarrow$ REDUCE VULNERABILITY

ASSETS $\rightarrow$ EXPAND OPPORTUNITIES 


\section{Savings Account Description}

- Based on Safe Spaces

Model to build girls social, human and economic assets

- Groups of 20-25 girls, ages 10-19 (two segments of groups)

- Girls within groups open individual savings accounts

- Weekly meetings in safe place provided by FI

- Mentors above age of 18 in each group facilitate group meetings and deliver financial education and health training

- Parents meetings \& fun days

- Benefits: ID, homebank, tshirt, friends

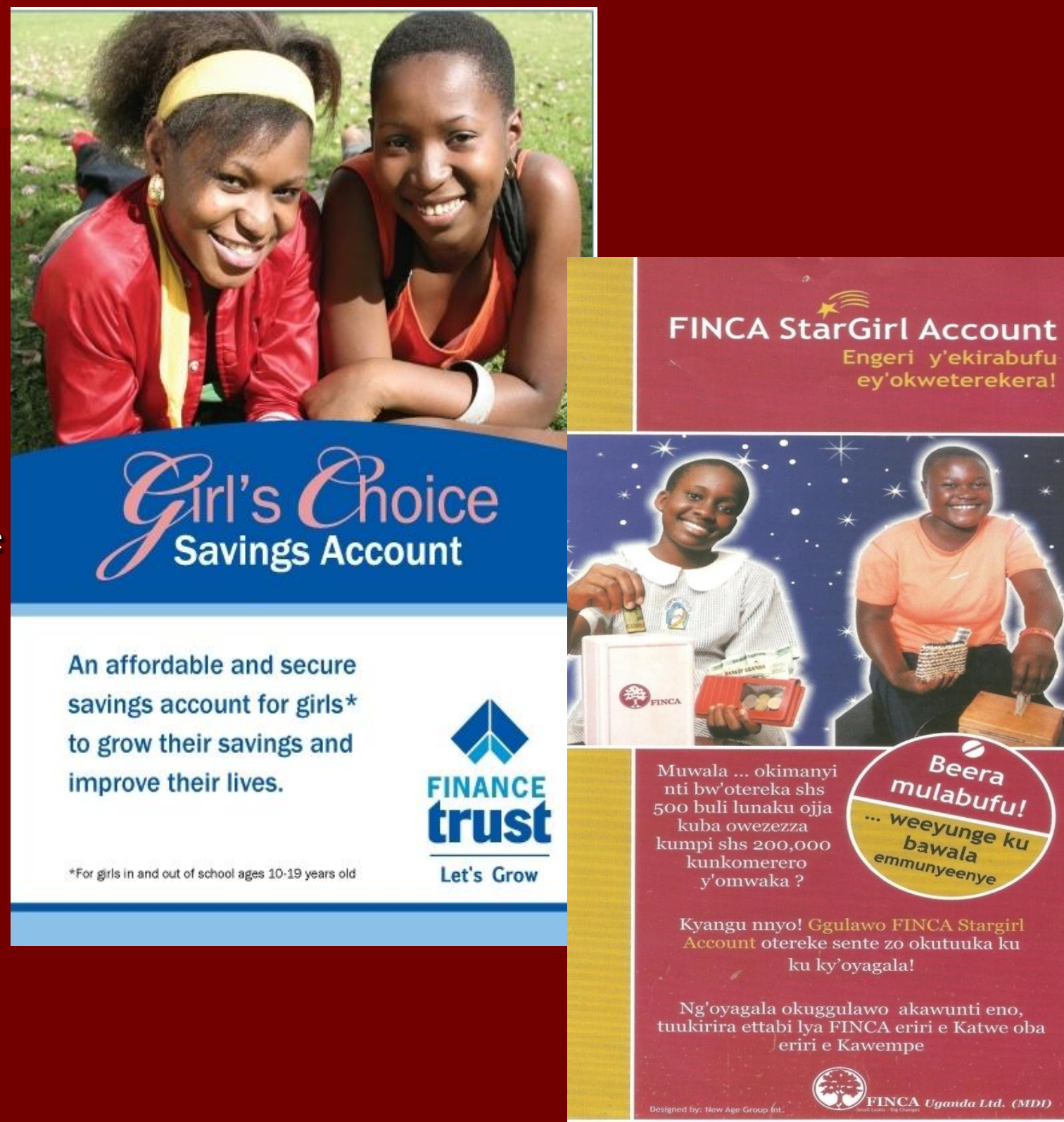




\section{Uganda Pilot Evaluation}

- Baseline: Girls interviewed within three weeks of opening savings account (Nov. 2009-Mar. 2010)

- FINCA - 543; FT - 518; Comparison - 503

- Endline: Girls interviewed 12 months after baseline (Nov. 2010 - Mar. 2011)

- FINCA - 392; FT - 437; Comparison - 330

- Matched pairs:

- FINCA - 371; FT - 389; Comparison - 316

- Behavior Change: not only for indicators of financial literacy and savings behavior, but also measures of social assets and health knowledge \& behavior 
Savings Account Only vs. Group +

\section{Savings Account}

- Girls asked at endline if they were a member of a group

- Of 760 matched intervention pairs, only $60 \%(n=456)$ were in a group

- No significant difference between FINCA and FT

- Why?

- Error in program implementation and recruitment guidelines

- $90 \%$ of girls not in group did not know they had the opportunity to join a group

- No significant difference between 'Group' and 'No Group' on age, religion, schooling status, living arrangements, personal asset owning, and household asset owning 


\section{Socio-Demographic Variables}

\begin{tabular}{|c|c|c|c|}
\hline Variable & FINCA & Finance Trust & Comparison \\
\hline $\mathrm{Age}^{\star \star \star}$ & & & \\
\hline $\begin{array}{l}-10-14 \\
-15-19\end{array}$ & $\begin{array}{l}62 \% \\
38 \%\end{array}$ & $\begin{array}{l}49 \% \\
51 \%\end{array}$ & $\begin{array}{l}71 \% \\
29 \%\end{array}$ \\
\hline Rellgionnn & & & \\
\hline $\begin{array}{l}\text {-Catholic } \\
\text {-Protestant } \\
\text {-Born Again } \\
\text {-Muslim }\end{array}$ & $\begin{array}{l}29 \% \\
24 \% \\
15 \% \\
22 \%\end{array}$ & $\begin{array}{l}20 \% \\
19 \% \\
15 \% \\
46 \%\end{array}$ & $\begin{array}{l}40 \% \\
25 \% \\
10 \% \\
25 \% \\
\end{array}$ \\
\hline Ever Married or Lived with Boyfriend & $4 \%$ & $5 \%$ & $3.5 \%$ \\
\hline $\begin{array}{l}\text { Education Status } \\
\text {-Ever Attended School }\end{array}$ & $99.5 \%$ & $99.5 \%$ & $99.7 \%$ \\
\hline -Currently in School & $88 \%$ & $90 \%$ & $95 \%$ \\
\hline $\begin{array}{l}\text {-Currently in Primary } \\
\text {-Currently in Secondary } \\
\text {-Currently in Post- } \\
\text { Secondary/Vocational }\end{array}$ & $\begin{array}{l}55 \% \\
41 \% \\
4 \%\end{array}$ & $\begin{array}{l}43 \% \\
53 \% \\
4 \%\end{array}$ & $\begin{array}{l}53 \% \\
44 \% \\
3 \%\end{array}$ \\
\hline $\begin{array}{l}\text { Literacy } \\
\quad \text {-Read Easily }\end{array}$ & $69 \%$ & $77 \%$ & $65 \%$ \\
\hline $\begin{array}{l}\text { Living Arrangements } \\
\text {-Mother Only } \\
\text {-Father Only } \\
\text {-Both Parents } \\
\text {-Neither Parent }\end{array}$ & $\begin{array}{l}31 \% \\
4 \% \\
45 \% \\
19 \%\end{array}$ & $\begin{array}{l}34 \% \\
5 \% \\
40 \% \\
21 \% \\
\end{array}$ & $\begin{array}{l}24 \% \\
7 \% \\
45 \% \\
24 \%\end{array}$ \\
\hline $\begin{array}{l}\text { Physical Asset OWnIng } \\
\text {-Household Assets (out of five - } \\
\text { electricity, radio, tv, phone, bed) }\end{array}$ & 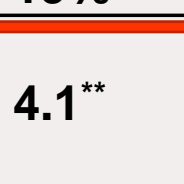 & $4.3^{*}$ & 3.8 \\
\hline
\end{tabular}




\section{Girls more likely to engage in work activity and use their own savings as a source of money}

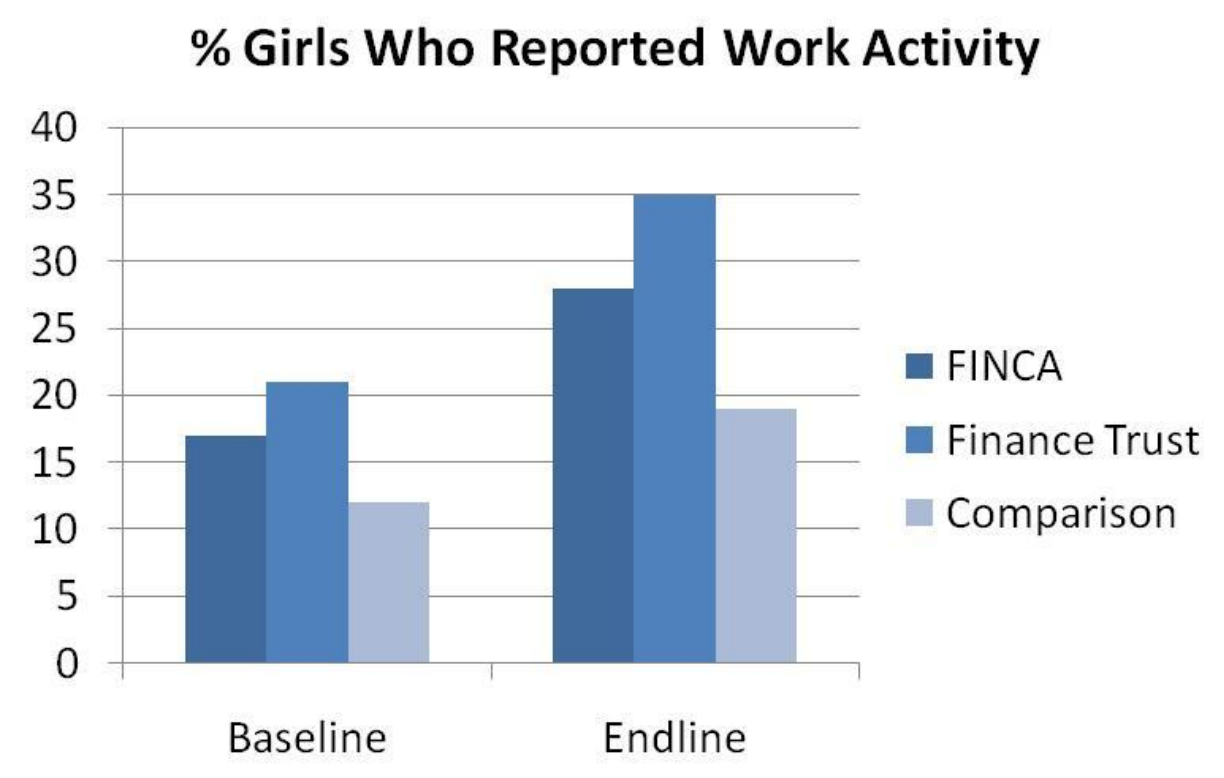

Outcome measures

FINCA

Finance Trust (Ref: control) (Ref: control) $1.57^{\star *}$ $1.81^{\text {** }}$
\% Girls With Their Own Savings as a Source from Where They Get Money

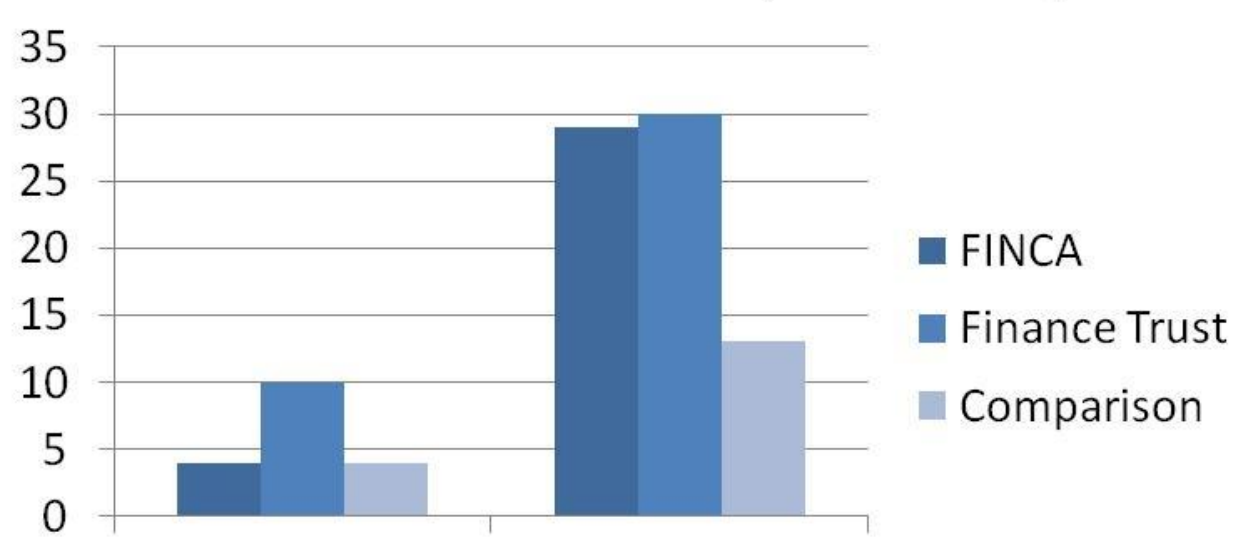

Baseline

Endline

\begin{tabular}{|c|c|c|}
\hline Outcome measures & $\begin{array}{c}\text { FINCA } \\
\text { (Ref: control) }\end{array}$ & $\begin{array}{l}\text { Finance Trust } \\
\text { (Ref: control) }\end{array}$ \\
\hline $\begin{array}{l}\text { Own Savings as } \\
\text { Source of Money }\end{array}$ & $2.68^{\star \star}$ & $2.78^{\star \star}$ \\
\hline
\end{tabular}




\section{Savings Behavior}

Girls more likely to save and to do so using formal and informal methods

- 25\% (FINCA) and 32\% (Finance Trust) increase in girls reporting saving in last six months. No increase in saving among comparison group

- $75 \%$ of girls with accounts reported saving in last 6 months - Girls 4.2 and 4.7 times more likely to save than comparison group

-Drastic increase in girls using formal methods

-Majority of girls still using mix of formal and informal

\begin{tabular}{|l|l|l|l|l|l|l|}
\hline Savings Method & \multicolumn{2}{|c|}{ FINCA } & \multicolumn{2}{c|}{ Finance Trust } & \multicolumn{2}{c|}{ Comparison } \\
\hline & Baseline & Endline & Baseline & Endline & Baseline & Endline \\
\hline Informal Only & $95 \%$ & $15 \%$ & $86 \%$ & $9 \%$ & $92 \%$ & $88 \%$ \\
\hline Formal Only & $0 \%$ & $7 \%$ & $2 \%$ & $12 \%$ & $2 \%$ & $4 \%$ \\
\hline Both formal and informal & $\mathbf{2 5 \%}$ & $78 \%$ & $12 \%$ & $79 \%$ & $6 \%$ & $8 \%$ \\
\hline
\end{tabular}




\section{Girls more likely to have a savings plan and a budget and save more money}

- Girls in program 1.5 times more likely to have a savings plan and a budget than comparison group

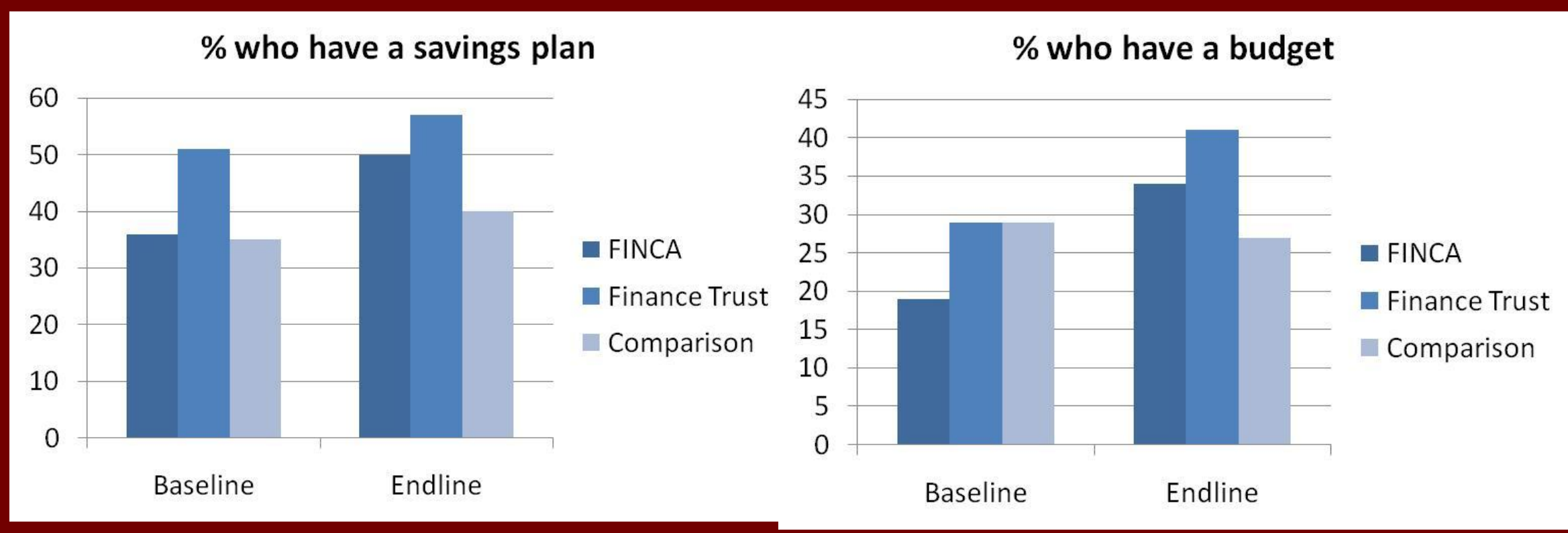

- Mean savings more than doubled between baseline and endline

- FINCA: $\$ 6.50$ to $\$ 16.28$; Finance Trust: $\$ 11.91$ to $\$ 25.54$

- More likely to have been in a bank and used bank services

- $13 \%$ of girls had household member open account after they did 
When comparing girls with groups and account vs. girls with accounts only, there was little difference in savings behavior

- There was no difference between girls with and without a group in terms of account balance, size of deposit, and frequency of deposits

- Girls who were not in a savings group made more withdrawals in six months prior to the interview ( 3 vs. 1.7)

- Girls in a group were more likely to say they would be likely to open an account with the same financial institution in the future $(85 \%$ v. $78 \%, p=0.030)$ 


\section{Girls in groups have higher social capital and stronger social networks}

- Girls in a savings group are more likely to agree that people in their neighborhood trust one another

\begin{tabular}{|l|l|l|l|}
\hline & Baseline & Endline & p-value \\
\hline Group + Savings Account & $48 \%$ & $56 \%$ & 0.012 \\
\hline Savings Account Only & $44 \%$ & $48 \%$ & 0.279 \\
\hline Comparison Group & $47 \%$ & $50 \%$ & 0.351 \\
\hline
\end{tabular}

- No sig. difference between groups at baseline, significant at endline

- Girls in savings group more likely to have someone to borrow money from in an emergency

- Increase for all groups, but greatest for girls with groups (31\% increase vs. $25 \%$ and $19 \%$ ) 
Girls with an account only more likely to be sexually harassed and teased by males than girls with accounts and groups

- Girls without a group were two times more likely to have been touched indecently by a male $(\mathrm{OR}=1.963)$

\begin{tabular}{|l|l|l|l|}
\hline & Baseline & Endline & p-value \\
\hline Group + Savings Account & $7.2 \%$ & $7.5 \%$ & 1.000 \\
\hline Savings Account Only & $9 \%$ & $14.5 \%$ & 0.044 \\
\hline Comparison Group & $10.8 \%$ & $7.6 \%$ & 0.193 \\
\hline
\end{tabular}

- Girls without a group had an increase in being teased by the opposite sex (no change for girls in group)

\begin{tabular}{|l|l|l|l|}
\hline & Baseline & Endline & p-value \\
\hline Group + Savings Account & $24 \%$ & $24 \%$ & 0.937 \\
\hline Savings Account Only & $19 \%$ & $26 \%$ & 0.029 \\
\hline Comparison Group & $24 \%$ & $20 \%$ & 0.326 \\
\hline
\end{tabular}




\section{Self Esteem and Gender Norms}

- Girls with no group were more likely to agree that they "sometimes" feel worthless than girls with a group $(\mathrm{OR}=1.61)$

\begin{tabular}{|l|l|l|l|}
\hline & $\begin{array}{l}\text { Savings Account } \\
\text { Only }\end{array}$ & $\begin{array}{l}\text { Group + Savings } \\
\text { Account }\end{array}$ & p-value \\
\hline Baseline & $26 \%$ & $22 \%$ & 0.173 \\
\hline Endline & $32 \%$ & $22 \%$ & 0.002 \\
\hline
\end{tabular}

- Girls in a savings group more likely at end line to disagree that men rape girls because they can't control themselves

\begin{tabular}{|l|l|l|l|}
\hline & $\begin{array}{l}\text { Savings Account } \\
\text { Only }\end{array}$ & $\begin{array}{l}\text { Group + Savings } \\
\text { Account }\end{array}$ & p-value \\
\hline Baseline & $44 \%$ & $47 \%$ & 0.518 \\
\hline Endline & $48 \%$ & $58 \%$ & 0.018 \\
\hline
\end{tabular}




\section{Girls with a group are more likely to have future life goals}

- There was no significant difference at baseline between girls with and without groups, but at endline girls with a savings group were significantly more likely to have the following future goals:

- Long term education goal ( $94 \%$ v. $88 \%, p=0.004)$

- Short term employment goal $(77 \%$ v. $72 \%, \mathrm{p}=0.048)$

- Long term employment goal ( $82 \%$ v. $74 \%, p=0.016)$ 


\section{Girls with groups have higher HIV/RH Knowledge}

- Name at least one correct method of HIV transmission (3.5 times more likely)

\begin{tabular}{|l|l|l|l|}
\hline & Baseline & Endline & p-value \\
\hline Group + Savings Account & $90 \%$ & $96 \%$ & 0.000 \\
\hline Savings Account Only & $89 \%$ & $88 \%$ & 1.000 \\
\hline
\end{tabular}

- Know that you can do something to prevent HIV (2 times more likely)

\begin{tabular}{|l|l|l|l|}
\hline & Baseline & Endline & p-value \\
\hline Group + Savings Account & $91 \%$ & $96 \%$ & 0.016 \\
\hline Savings Account Only & $90 \%$ & $92 \%$ & 0.402 \\
\hline
\end{tabular}




\section{HIV/RH Knowledge - Cont'd}

- Know at least one method of family planning (3 times more likely)

\begin{tabular}{|l|l|l|l|}
\hline & Baseline & Endline & p-value \\
\hline Group + Savings Account & $74 \%$ & $88 \%$ & 0.000 \\
\hline Savings Account Only & $76 \%$ & $77 \%$ & 0.731 \\
\hline
\end{tabular}

- More likely to have had an HIV test $(\mathrm{OR}=1.48, \mathrm{p}=0.027)$

\begin{tabular}{|l|l|l|l|}
\hline & Baseline & Endline & p-value \\
\hline Group + Savings Account & $31 \%$ & $43 \%$ & 0.000 \\
\hline Savings Account Only & $36 \%$ & $39 \%$ & 0.342 \\
\hline
\end{tabular}




\section{Implications for the Way Forward}

- Strong increase in savings and financial literacy indicators

- Being in the group and having a savings account builds social, health and economic assets for girls

- Only having a savings account only build economic

- Only having a savings account could put girls at risk of sexual harassment

- The group seems does not have a strong effect on savings balances, but it does influence withdrawals

- Scale up should include group component, but will likely need external (i.e. non-bank) funding 


\section{ASAN'TENI - THANK YOU}
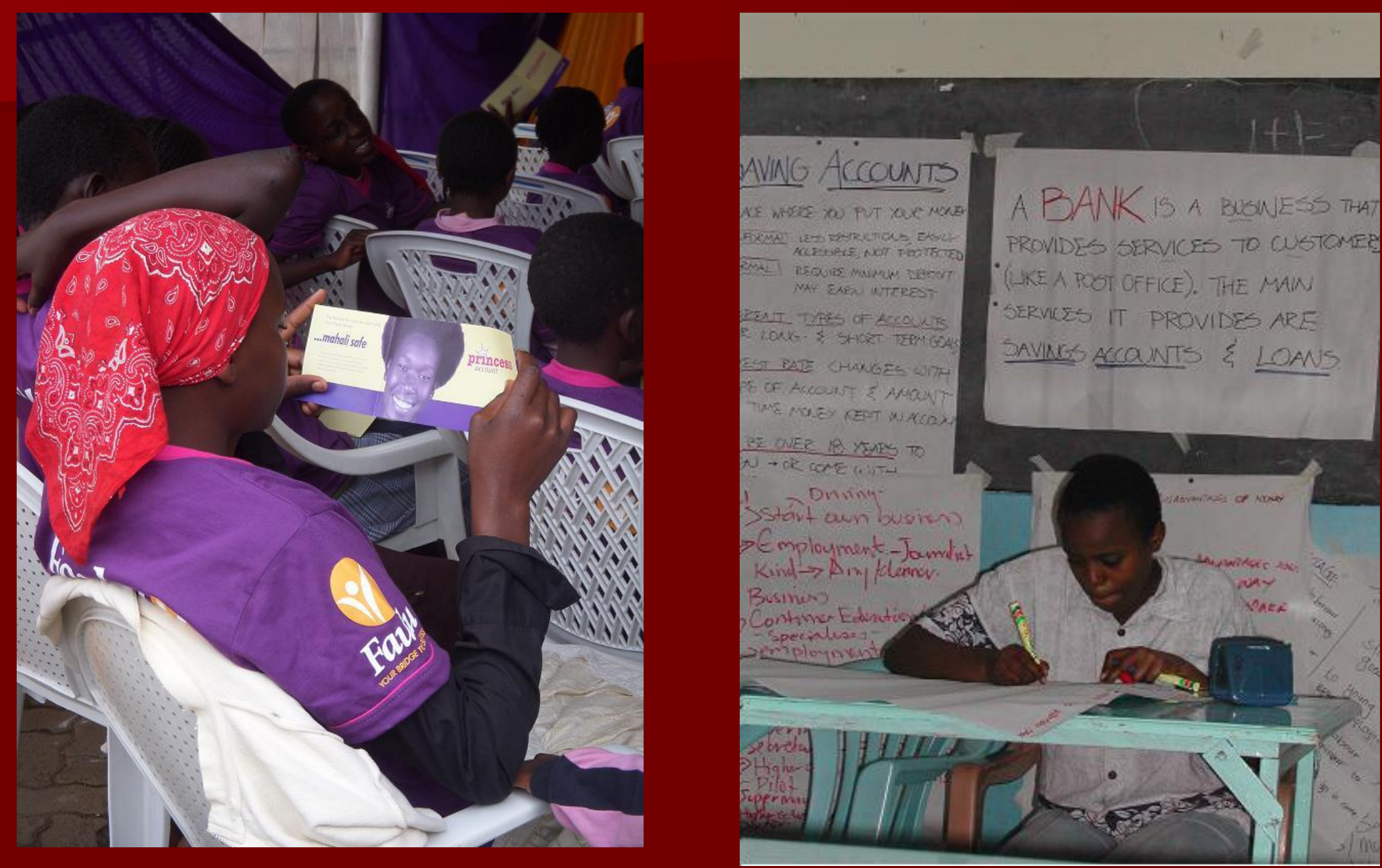

For More Information - contact Karen Austrian at kaustrian@popcouncil.org 